JOANNA BUŁAWA-HALASZ University of Szczecin

\title{
Requirements for the teacher-therapist of persons with autism spectrum disorder - challenges for the new specialisation
}

\begin{abstract}
Joanna Buława-Halasz, Requirements for the teacher-therapist of persons with autism spectrum disorder - challenges for the new specialisation. Interdisciplinary Contexts of Special Pedagogy, no. 27, Poznań 2019. Pp. 335-349. Adam Mickiewicz University Press. ISSN 2300-391X. e-ISSN 2658-283X. DOI: https://doi.org/ 10.14746/ikps.2019.27.15

The text concerns the introduced standards for educating teachers-therapists of persons with autism spectrum disorder. This new specialisation in special pedagogy is meant to respond to the needs of autistic people, but its form is not fully responsive to real needs in this area.
\end{abstract}

KEY WORDS: autism spectrum disorder, teacher-therapist of autistic people

\section{Introduction}

This text was inspired by the Ordinance announced on 2 August 2019 on Education Standards in Preparation for Work as a Teacher ${ }^{1}$ introducing a long awaited specialisation in education of special

${ }^{1}$ The Ordinance of the Minister of Science and Higher Education of 2019 on Education Standards in Preparation for Work as a Teacher, Journal of Laws 2019, item 1450, <prawo.sejm.gov.pl/isap.nsf/DocDetails.xsp?id=WDU20190001450> [14.08.2019]. 
pedagogues concerning education and therapy of persons with autism spectrum disorder. The article is aimed at drawing attention to the need of thinking over the manner of developing professionalism of this group; it is intended to inspire reflection on the conception of not primarily education, but rather development of a teacher-therapist of persons with autism spectrum disorder, and the requirements will be high, since such special pedagogue is expected to, apart from substantive and theoretical interdisciplinary background, have many practical skills and internal predispositions. ${ }^{2}$

It is worth noticing that the term "autism spectrum disorder" ASD; from the group of neurodevelopmental disorders has been introduced in the $\mathrm{Act}^{3}$ from the ICD- $11^{4}$ classification not yet binding in Poland. It is a good step, since the standard does not become outdated upon implementation. Whereas, using by the legislator plural in "autism spectrum disorders" instead of "disorder" 5 constitutes negligence; perhaps it results from being used to the previously used term "pervasive development disorders".

The process of creating a specialisation in pedagogy aimed at autistic persons' needs was very long. In 2012 educational standards

${ }^{2}$ M. Zaorska, The Role and Place of a Special Pedagogue in Creating the EducationalTherapeutic Activity (Rola i miejsce pedagoga specjalnego w kreowaniu dziatalności edukacyjno-terapeutycznej), [in:] “Acta Universitatis Nicolai Copernici. Pedagogy XXVIII/2012. Humanities and Social Science" ("Acta Universitatis Nicolai Copernici. Pedagogika XXVIII/2012. Nauki Humanistyczno-Społeczne") 2012, journal 405. Torun: Nicolaus Copernicus University in Torun, <https://repozytorium.umk.pl/bitstream/handle/ item/640/AUNC_PED.2012.001,Zaorska.pdf?sequence=1> [5.04.2019], p. 15.

${ }^{3}$ ICD-11: <https://icd.who.int/browse11/1-m/en\#/http://id.who.int/icd/enti ty/437815624> [15.05.2019].

${ }^{4}$ WHO: <https://www.who.int/classifications/icd/en/> [15.05.2019]; implementation is planned for 2022; cf.: ICD-10. (2008). International Statistical Classification of Diseases and Related Health Problems. (Międzynarodowa Statystyczna Klasyfikacja Chorób i Problemów Zdrowotnych.) Tenth Revision. Volume I. World Health Organization. Centre of Health Information Systems, <https://www.csioz. gov.pl/fileadmin/user_upload/Wytyczne/statystyka/icd10tomi_56a8f5a554a18.pdf> [14.10.2019].

${ }^{5}$ The "disorder" term will be used herein. 
preparing for work as a teacher were introduced in the following specialisations: 1. Education and rehabilitation of persons with intellectual disability; 2. Typhlopedagogy; 3. Surdopedagogy; 4. Medical Pedagogy; 5. Resocialization and sociotherapy. ${ }^{6}$ However, a specialisation concerning education of teachers aimed at working with an autistic person was missing and it was introduced only after nine years as of recognising autism as a disability.

The aforementioned ordinance of 2019 stipulates that key areas on which the teacher's professionalism is constructed include: substantive and didactic-methodological background and internship, as well as support for the special pedagogue workshop (including voice emission, language culture, first aid, ICT technologies) and scientific research methodology. The first three included detailed description of requirements from a graduate consisting in knowledge, skills and social competences. ${ }^{7}$ The latter, in order to underline their importance, will be discussed as a separate part. Support for the workshop and methodology will be omitted, since they are universal for all addressees of the ordinance, not only teachers-therapists of autistic persons.

\section{Substantive preparation of a teacher-therapist of persons with autism spectrum disorder}

The substantive preparation concerns medical and psychological-pedagogical aspects. During studies, a candidate for a teacher of persons with ASD should gain knowledge and skills in the scope of medical basis of the disorder, anatomy and physiology of the nervous system in the context of developmental deficits and irregularities in autism, genetic disorders and multiple disabilities, psy-

6 The Ordinance of the Minister of Science and Higher Education of 17 January 2012 on Education Standards in Preparation for Work as a Teacher, Journal of Laws 2012, item 131.

7 The Ordinance of the Minister of Science and Higher Education of 25 July 2019 ..., op. cit. 
chiatry and psychopathology and neurology, childhood diseases and selected medical problems concerning persons with ASD: diet, supplementation, pharmacotherapy. A student should also learn about tools to monitor health condition of children, diagnostic criteria, conditions and epidemiology of $\mathrm{ASD}$, description of disorders in medical nosology classifications (ICD, DSM) and functional classification (ICF), as well as know the principles of differential diagnosis from hearing damage, intellectual development disorders and other disorders and disabilities. ${ }^{8}$ This part includes components of knowledge and skills, which each teacher-therapist of autistic persons should be equipped with sufficiently.

The knowledge and skills in the scope of the psychologicalpedagogical basis and preventative-supportive measures constitute the grounds of neuropsychology, knowledge of other neurodevelopmental disorders. A student should learn about the psychological characteristics of persons with ASD at various development stages, as well as master the knowledge and skills in the scope of recognising early symptoms of autism and the meaning of physical environment, stimulation and sensor integration in autism. Furthermore, the knowledge on the characteristics of cognitive, emotional and social functioning in ASD, as well as regularity in speech, language and communication is extremely important. Moreover, the legislator stipulates that it is important to learn about the psychopedagogical diagnosis of autism spectrum students, in particular, functional profiles, as well as to learn about diagnostic methods and tools with a special consideration of the international "gold standard of diagnosis" ADI-R (Autism Diagnostic Interview-Revised) and ADOS (Autism Diagnostic Observation Schedule). In the case of autistic persons, it is crucial to have knowledge and skills in the scope of the augmentative and alternative communication (AAC). Furthermore, the role of a computer, media and new technologies in therapy of persons with ASD is also indicated. Moreover, the legislator indicates the contents in the scope of psychological-pedagogical

${ }^{8}$ Ibidem. 
methods used in autism therapy with reference to the evidence base practice, including ESDM (the Early Start Denver Model). The need to acquire knowledge and skills regarding the principles of behaviour correction and solving educational problems is presented. Furthermore, a student should know various approaches to education and forms of work and therapy, including educational-therapeutic models and selected methods. Preparation to work with parents/carers of a person with ASD, including providing therapeutic support and psycho-social support to the family and person with ASD also in their adult lives and, therefore, knowledge on the employment-related problems is important as well. ${ }^{9}$

The contents included by the legislator in this part of the ordinance should be analysed critically. A question may be asked about the manner of awarding qualifications during studies to use ADI-R and ADOS tools by graduates. The guidelines explicitly state who can be deemed as a competent user of the discussed tools; those are solely the persons, who attended a relevant training authorising the results of their studies to be deemed as reliable and trustworthy. ${ }^{10}$

It is also not justified to specify any single therapeutic method in the ordinance (in this particular one - ESDM). There are many various interventions aimed at helping autistic persons ${ }^{11}$, and a selec-

9 Ibidem.

10 A. Rynkiewicz, B. King, K. Kalisz, A. Słopień, M. Janas-Kozik, I. Łucka, Competent Users and Standards of Using the Autism Diagnostic Interview - Revised ADI-R and the Autism Diagnostic Observation Schedule Second Edition ADOS-2 (Kompetentni uzytkownicy $i$ standardy użytkowania wywiadu do diagnozowania autyzmu ADI-R (Autism Diagnostic Interview - Revised) oraz protokotu obserwacji do diagnozowania zaburzeń ze spektrum autyzmu ADOS-2 (Autism Diagnostic Observation Schedule, Second Edition)), [in:] “Clinical Psychiatry and Psychology” („Psychiatria i Psychologia Kliniczna”) 2018, no. 18(4), pp. 400-401, <http://www.psychiatria.com.pl/index.php/wydawnic twa/2018-vol-18-no-4/kompetentni-uzytkownicy-i-standardy-uzytkowania-wywia du-do-diagnozowania-autyzmu-adi-r-autism-diagnostic-interview-revised-oraz-pro tokolu-obserwacji-do-diagnozowania-zaburzen-ze-spektrum-autyzmu-ados-2-autismdiagnostic-observ?aid=795> [14.08.2019].

11 <http:/ / www.researchautism.net/autism-interventions/introduction-autisminterventions $>$ [14.08.2019]. 
tion thereof depends on the individual needs of a person with ASD. Such selection is extremely difficult for several reasons. It may rarely be determined exactly, what are the sources of changes in development. Effectiveness of various impacts in the case of particular persons is varied; symptoms may spontaneously improve. Creating properly controlled scientific studies may be difficult and sometimes even impossible. Scientists may have commercial interests in proving success of the intervention and persons engaged in the intervention may want it to work so much that they see a significant change where it is missing. ${ }^{12}$ Significant problems are also connected with stipulating effectiveness indicators of the influences and measurement thereof. ${ }^{13}$ Nevertheless, all of the above factors do not mean that teachers-therapists do not have tools with which they can try to find a proper approach - before using in practice, each intervention should be assessed on the grounds of the quantity and quality of scientific evidence published in reviewed magazines or scientific publications. Unfortunately, knowledge and skills in this scope are not developed during pedagogical studies, which may be proved by the common use of the "Educational Kinesiology" method by Paul Dennison despite the scientific evidence proving its ineffectiveness. ${ }^{14}$

It is only a fragment of the problem, which is very complex and which concerns the relation between academic and non-academic education together with the commercial training market. It is a broad

12 Ibidem.

${ }^{13}$ E. Pisula, Effectiveness of Therapy and Education in Persons with Autism Spectrum Disorder (Efektywność terapii i edukacji osób z zaburzeniami należącymi do autystycznego spectrum), <https://www.slideshare.net/crisma61/efektywno-terapii-i-edukacji-osobz-zaburzeniami-nalezacymi-do-autystycznego-spektrum-14291559> [14.08.2019].

14 Neurobiology Committee of the Polish Academy of Science (Komitet Neurobiologii Polskiej Akademii Nauk), Opinion on the Scientific Bases for the "Educational Kinesiology" Method and Consequences of Using it (Opinia dotyczaca podstaw naukowych metody "Kinezjologii Edukacyjnej” oraz konsekwencji jej stosowania), Warsaw 2006, <http://www.kneurobiologii.pan.pl/images/stories/opinia\%20dotyczaca\%20podstaw \%20naukowych\%20metody\%20kinezjologii\%20edukacyjnej\%20oraz\%20konsekwencji \%20ich\%20stosowania.pdf> [15.08.2019]. 
issue - too broad to be sufficiently described in a short form of an article. However, it is worth paying attention to it, since it may constitute a barrier in meeting expectations of the standard's creators. A special emphasis should be put on developing the skill of assessing methods critically by teachers-therapists.

\section{Didactic-methodological preparation of a teacher-therapist of persons with autism spectrum disorder}

In the part devoted to the didactic-substantive preparation of the ordinance, the meaning of knowledge and skills in the scope of the methodology of early support of development of a child with ASD and a multidisciplinary assessment of the level of their functioning, as well as planning the didactic-educational and therapeutic works with children and youth, as well as adjusting educational requirements to the needs of students with ASD, is underlined. It is indicated that knowledge and skills in the scope of co-organising didactic classes by a teacher supporting a student with ASD and other neurodevelopmental disorder, as well as specialist classes, comprehensive and interdisciplinary rehabilitation and methodology of individual rehabilitation classes, are important. During studies, a student is supposed to learn about the methodology of social skills' trainings and activating classes in a school group, as well as learn to develop their interests and passions regarding counselling and supporting professional development of autistic persons. ${ }^{15}$

What may be above all noticed in the aforementioned part, is the "negligence" of adult autistic persons in the process of "planning didactic-educational and therapeutic work", whereas, education of students with disabilities can be carried out until 20 years of age in an elementary school or until 24 years of age in a secondary school. ${ }^{16}$

15 The Ordinance of the Minister of Science and Higher Education of 25 July 2019 ..., op. cit.

16 The Ordinance of the Minister of National Education of 9 August 2017 on the Rules of Organising Education, Upbringing and Care for Children and Youth with 
In accordance with the ordinance, passions and interests of autistic persons can be developed only in the aspect of occupational preparation. Taking into account the rigid and limited assortment of interests and behaviours of autistic persons, it would be appropriate to develop them, limit stereotypes, auto-stimulations or fixations, develop social skills or simply teach how to spend free time. ${ }^{17}$

\section{Internship of a teacher-therapist of persons with autism spectrum disorder}

The legislator stipulated that in the scope of knowledge, during internship a student should learn about and understand tasks' characteristics for a kindergarten, a school or an education system facility, as well as environment in which they operate, learn about their organisation, statute, plan of work and educational-preventative programme, as well as learn about the principles of providing children and students with safety at the aforementioned places and outside of them. A student should draw conclusions from observing teachers' work, their interactions with children and students and the manner in which they plan and carry out didactic, educational and care classes, as well as from observing the manner of integrating care and educational activities with didactic activities and from directly observing extracurricular care and educational activities of teachers, including, at duty hours during breaks between classes and organised trips of student groups. Then, the student should plan and conduct classes themselves under supervision of an in-

Disabilities, Socially Maladjusted and at a Risk of Social Maladjustment, Journal of Laws 2017, item 1578, Article 4, <http:// prawo.sejm.gov.pl/isap.nsf/download.xsp/ WDU20170001578/O/D20171578.pdf> [15.08.2019].

${ }^{17}$ For more information on this topic see: J. Buława-Halasz, Social and Professional Rehabilitation of Autistic Adults. Phenomenographic Case with the Use of Social Theory by Pierre Bourdieu (Rehabilitacja społeczna i zawodowa dorostych osób autystycznych. Studium fenomenograficzne z zastosowaniem teorii społecznej Pierre'a Bourdieu), Oficyna Wydawnicza „Impuls”, Kraków 2017. 
ternship supervisor, as well as analyse, with the support of the internship supervisor and academic teachers, conducted classes in the scope of the psychological-pedagogical preparation, pedagogical situations and events observed or experienced during internship. In the scope of social competences, the student should be ready to effectively cooperate with the internship supervisor and teachers in order to extend their knowledge. ${ }^{18}$

If a student is referred to a facility, where the staff suffer from burnout, are tired, their activities are routine, not creative and stimulating the development of wards enough, then, a student might experience a reality shock, that is, disappointment related to the clash of expectations with reality. ${ }^{19}$ A student will not, in fact, be challenged with a statute or a plan of work, but with school culture, unwritten principles, a system of interdependencies and interrelations, working conditions, atmosphere, everyday life problems concerning didactics etc. ${ }^{20}$ In order not to waste students' potential, it is worth sending them to undergo internship at facilities accredited by relevant authorities, which becomes a standard in European countries $^{21}$, or where a professional supervision is carried out, aimed at increasing effectiveness of individual work, professional development, improving the quality of the facility's operations ${ }^{22}$, or which

18 The Ordinance of the Minister of Science and Higher Education of 25 July 2019 ..., op. cit.

${ }^{19}$ C. Cherniss, Professional burnout in human service organizations. Westport, CT: Praeger, 1980; as quoted in: T. Chmiel, Visions and (re)visions of Preparation for a Teacher Profession (Wizje i (re)wizje przygotowania do zawodu nauczyciela), Dolnośląska Szkoła Wyższa, Wroclaw 2014, p. 78.

${ }^{20}$ T. Chmiel, Visions and (re)visions of Preparation for a Teacher Profession (Wizje $i$ (re)wizje przygotowania do zawodu nauczyciela), Dolnośląska Szkoła Wyższa, Wroclaw 2014, p. 78.

${ }^{21} \mathrm{H}$. Morgan, Adults with Autism. Theory and Practice (Dorośli z autyzmem. Teoria i praktyka), Fundacja Wspólnota Nadziei, Krakow 2004, pp. 69-89.

22 D. Kohut, A Therapist and His Personality in the Context of Occupational Burnout Syndrome (Terapeuta i jego osobowość w kontekście syndromu wypalenia zawodowego), [w:] A Child with Special Needs in the Interdisciplinary Therapy (Dziecko o specjalnych potrzebach w kregu interdyscyplinarnej terapii), ed. D. Kohut, Krakow 2013, p. 315. 
at least uses other forms of development: mentoring, playing a role of a critical friend, colleague visitations, job rotation, analysis of critical events or keeping a professional journal. ${ }^{23}$

\section{Social competences of a teacher-therapist of persons with autism spectrum disorder - expectations vs. reality}

According to the legislator, social competences of a graduate in the scope of substantive preparation can include readiness to autoreflection on professional development and use of acquired knowledge to analyse pedagogical events; in the didactic-methodological scope include the ability to show empathy to children and students in need of support and assistance, professional resolution of conflicts in a class or peer group, explore pedagogical knowledge independently and cooperate with teachers in order to improve own skills and tools. ${ }^{24}$

Therapists of autistic persons should have the following features: extensive knowledge, a high level of intelligence, good creative skills, high self-assessment, no tendency to authoritarianism and dogmatism, flexibility, a low level of neuroticism and fear, calmness, ability to empathy, internal feeling of control, significant professional experience, an extensive scope of contacts with autistic persons, appropriate perception of own assistance skills. ${ }^{25}$ The profession of a teacher-therapist belongs to a group of assistance professions ${ }^{26}$ and as such should be also characterised with joy of living,

${ }^{23}$ C. Plewka, Conditions of Professional Development of Teachers (Uwarunkowania zawodowego rozwoju nauczycieli), Wydawnictwo Instytutu Badań Edukacyjnych, Warsaw 2009.

24 The Ordinance of the Minister of Science and Higher Education of 25 July 2019 ..., op. cit.

25 J. Buława-Halasz, op. cit., p. 292.

${ }^{26}$ Expert opinion Psychophysical Burdens in Teaching Profession and Their Impact on Health (Obciażenia psychofizyczne w zawodzie nauczyciela $i$ ich wptyw na zdrowie, compiled under supervision of Professor Mariola Śliwińska-Kowalska, MD, PhD, Lodz 2004, <http://old.pomorskie.znp.edu.pl/nowe_pliki/ekspertyza.doc> [19.05.2019]. 
acceptance of change, a lack of conformism, openness, absorption of mind, self-awareness, authenticity, self-knowledge. ${ }^{27}$ Unfortunately, the reality is different: "in a traditional public, state school employed persons are to a large extent tired with their work, resistant to changes, imitative, thoughtless, treating their role in a narrow manner, as a duty, achieving professional promotion levels only to rest on their laurels after obtaining the title of a chartered teacher. They fall into a routine, are attached to patterns and transmissive function of an educational institution, searching for the genesis of their limitations, but also hope for a change in external factors (changing the organisation of the school, educational law, provisions, curricula, requirements and duties), but not in themselves". ${ }^{28}$ Answers to the question what it is like this is given in the next part.

\section{Conclusion}

Donald A. Schön states that some observers of social life noticed a tendency for de-professionalisation and among diversified professional groups such as: engineers, teachers, musicians, scientists, doctors or statisticians, the labour market weakened and the economic status and working conditions decreased. Furthermore, the author notices that the crisis in trust to professions and perhaps also the decrease in the professional image of self seems to be rooted in the growing scepticism regarding the professional effectiveness in broad understanding, a sceptical assessment of the actual contribution of professions in the prosperity of a society by providing competent services on the grounds of a special knowledge. ${ }^{29}$ In this con-

${ }_{27}$ M. Davies, Using the Resources of Own "Ego" by a Social Worker. (Czerpanie przez pracownika socjalnego z zasobów własnego "Ja"). Fragments of tenth chapter of the book by M. Davies entitled "The Essential Social Worker. A Guide to Positive Practice", Wildwood House, Gower House, 1985, [in:] Social Work. Social Aid (Praca socjalna. Pomoc społeczna), selection and compilation by J. Kwaśniewski, Interart, Warsaw 1998, p. 111.

28 T. Chmiel, op. cit., p. 78.

${ }^{29}$ Schön D.A., The reflective practitioner. How professionals think in action, Basic Books, London and New York 1983, p. 13. 
text, it is worth mentioning the text written by Amadeusz Krause published in 2014 in Rocznik Pedagogiczny "About Deterioration of Pedagogy - Deliberations on the Grounds of Experience of PKA Member" („O psuciu pedagogiki - rozważania na kanwie doświadczeń członka PKA") and his deliberations as a Member of the Polish Accreditation Committee ${ }^{30}$ regarding the quality of exercising this scientific discipline. Both, after over 35 years of writing the book by Schön and after several years of writing the text by Krause, both works remain valid, which is confirmed with the report of the Supreme Audit Committee (NIK) entitled "NIK about the preparation to the work as a teacher" from March 2017.31

NIK underlines the lack of mechanisms and tools to select candidates to work as a teacher and, in particular, a lack of universities' recruitment criteria, not monitoring usefulness of candidates to the profession during their education and the professional promotion procedures not fulfilling the screening role. Negative selection to the profession of a teacher is more and more visible - over nine percent of the total number of persons accepted at faculties with teacher specialisations are persons with the lowest results obtained at the secondary school final exam (between 30 and 49 points). The number of persons who fail to defend their dissertations and Master's theses on time is gradually growing (an increase by 10 percent in the years 2012-2015). Education of future teachers is also conducted by many various institutions which generates a risk of insufficient quality of education. To a certain extent it can be prevented with the provision in the ordinance on the educational standards of teachers that "education at postgraduate studies is undergone solely by persons participating in the education preparing to work as a teacher conducted by a university at first or second degree of studies or long-cycle Master's degree programme, at a faculty correspondent

30 The Polish Accreditation Committee (PKA) - an independent institution acting to the benefit of providing and improving the quality of education at Polish universities, <http://www.pka.edu.pl/misja/> [05.05.2019].

${ }^{31}$ The Supreme Audit Committee: <https://www.nik.gov.pl/aktualnosci/niko-przygotowaniu-do-zawodu-nauczyciela.html> [11.04.2019]. 
to the scope of education at postgraduate studies". ${ }^{32}$ Until now, it was a standard to conduct postgraduate studies with various specialisations of special pedagogy by universities which, at the same time, did not have first and second degree of studies in special pedagogy in their offer (and thus, relevant staff etc.). In the NIK's opinion, it would be also necessary to consider introducing an external state exam that would verify acquired teachers' competences in an objective manner. This type of solution is used in, among others, Germany. ${ }^{33}$

It is obvious that one should be content with creating a new specialisation in special pedagogy aimed at special needs of persons with autism spectrum disorder, however, the issue of requirements from a teacher-therapist - formulation and procedure of enforcement thereof - remains open.

\section{Bibliography}

[1] Buława-Halasz J., Rehabilitacja społeczna i zawodowa dorostych osób autystycznych. Studium fenomenograficzne z zastosowaniem teorii spotecznej Pierre'a Bourdieu, Oficyna Wydawnicza „Impuls”, Kraków 2017.

[2] Cherniss C., Professional burnout in human service organizations. Westport, CT: Praeger, 1980; as quoted in: T. Chmiel, Wizje i (re)wizje przygotowania do zawodu nauczyciela, Dolnośląska Szkoła Wyższa, Wrocław 2014.

[3] Chmiel T., Wizje i (re)wizje przygotowania do zawodu nauczyciela, Dolnośląska Szkoła Wyższa, Wroclaw 2014.

[4] Davies M., Czerpanie przez pracownika socjalnego z zasobów własnego "Ja". Fragments of tenth chapter of the book by M. Davies (1985) "The Essential Social Worker. A Guide to Positive Practice". Wildwood House, Gower House, translated by: H. Grzegołowska-Klarkowska, [in:] Praca socjalna. Pomoc społeczna, selection and compilation by J. Kwaśniewski, Interart, Warsaw 1998.

[5] Kohut D., Terapeuta i jego osobowość w kontekście syndromu wypalenia zawodowego [in:] Dziecko o specjalnych potrzebach w kregu interdyscyplinarnej terapii, ed. D. Kohut, Oficyna Wydawnicza „Impuls”, Kraków 2013.

32 The Ordinance of the Minister of Science and Higher Education of 25 July 2019 ..., op. cit., p. 70.

${ }^{33}$ T. Chmiel, op. cit., p. 106. 
[6] Krause A., O psuciu pedagogiki - rozważania na kanwie doświadczeń członka PKA, „Rocznik pedagogiczny” 2014, no. 37.

[7] Morgan H., Dorośli z autyzmem. Teoria i praktyka, Fundacja Wspólnota Nadziei, Krakow 2004.

[8] Pisula E., Efektywność terapii i edukacji osób z zaburzeniami należącymi do autystycznego spektrum, <https://www.slideshare.net/crisma61/efektywno-terapii-i-edu kacji-osob-z-zaburzeniami-nalezacymi-do-autystycznego-spektrum-14291559> [14.08.2019].

[9] Plewka C., Uwarunkowania zawodowego rozwoju nauczycieli, Wydawnictwo Instytutu Badań Edukacyjnych, Warsaw 2009.

[10] Rozporządzenie Ministra Edukacji Narodowej z dnia 9 sierpnia 2017 r. w sprawie warunków organizowania kształcenia, wychowania i opieki dla dzieci i młodzieży niepełnosprawnych, niedostosowanych społecznie i zagrożonych niedostosowaniem społecznym, Dziennik Ustaw 2017, item 1578.

[11] Rozporządzenie Ministra Nauki i Szkolnictwa Wyższego z dnia 17 stycznia 2012 r. w sprawie standardów kształcenia przygotowującego do wykonywania zawodu nauczyciela, Dziennik Ustaw 2012, item 131.

[12] Rozporządzenie Ministra Nauki i Szkolnictwa Wyższego z dnia 25 lipca 2019 r. w sprawie standardu kształcenia przygotowującego do wykonywania zawodu nauczyciela, Dziennik Ustaw 2019, item 1450.

[13] Rynkiewicz A., King B., Kalisz K., Słopień A., Janas-Kozik M., Łucka I., Kompetentni użytkownicy $i$ standardy użytkowania wywiadu do diagnozowania autyzmu ADI-R (Autism Diagnostic Interview - Revised) oraz protokotu obserwacji do diagnozowania zaburzeń ze spektrum autyzmu ADOS-2 (Autism Diagnostic Observation Schedule, Second Edition, [in:] „Psychiatria i Psychologia Kliniczna” 2018, no. 18(4), pp. 400-401, <http://www.psychiatria.com.pl/index.php/wydawnictwa/2018vol-18-no-4/kompetentni-uzytkownicy-i-standardy-uzytkowania-wywiadu-dodiagnozowania-autyzmu-adi-r-autism-diagnostic-interview-revised-oraz-proto kolu-obserwacji-do-diagnozowania-zaburzen-ze-spektrum-autyzmu-ados-2-au tism-diagnostic-observ?aid=795< [14.08.2019].

[14] Schön D.A., The reflective practitioner. How professionals think in action, Basic Books, London and New York 1983, <https:// books.google.pl/books?id=OT9B DgAAQBAJ\&printsec $=$ frontcover\&dq=inauthor:\%22Donald + A. + Sch $\%$ C3\% B6n \%22\&hl=pl\&sa=X\&ved=0ahUKEwi6hbWi48jhAhXrpIsKHdjSD9gQ6AEIKDAA $\# \mathrm{v}=$ onepage\&q\&f=false $>$ [11.04.2019].

[15] Wysocka E., Diagnostyka pedagogiczna. Nowe obszary i rozwiazania, Oficyna Wydawnicza „Impuls”, Krakow 2013.

[16] Zaorska M., Rola i miejsce pedagoga specjalnego w kreowaniu działalności edukacyjno-terapeutycznej, [in:] “Acta Universitatis Nicolai Copernici. Pedagogika XXVIII/2012. Nauki Humanistyczno-Społeczne" 2012, journal 405. Torun: Uniwersytet Mikołaja Kopernika, <https://repozytorium.umk.pl/bitstream/handle/item/640/ AUNC_PED.2012.001,Zaorska.pdf?sequence=1> [5.04.2019]. 
Internet sources

[1] Expert opinion Obciażenia psychofizyczne w zawodzie nauczyciela $i$ ich wptyw na $z$ drowie, compiled under supervision of Professor Mariola Śliwińska-Kowalska, MD, PhD, Lodz 2004, <http://old.pomorskie.znp.edu.pl/nowe_pliki/eksperty za.doc> [19.05.2019].

[2] ICD-10. (2008). Międzynarodowa Statystyczna Klasyfikacja Chorób i Problemów Zdrowotnych. Tenth revision. Volume I. World Health Organization. Centrum Systemów Informacyjnych Ochrony Zdrowia: <https://www.csioz.gov.pl/fileadmin/ user_upload/Wytyczne/statystyka/icd10tomi_56a8f5a554a18.pdf> [14.10.2019].

[3] ICD-11: <https://icd.who.int/browse11/l-m/en\#/http://id.who.int/icd/entity/ 437815624> [15.05.2019].

[4] Komitet Neurobiologii Polskiej Akademii Nauk, Opinia dotyczaca podstaw naukowych metody "Kinezjologii Edukacyjnej" oraz konsekwencji jej stosowania, Warsaw 2006, <http://www.kneurobiologii.pan.pl/images/stories/opinia\%20dotyczaca $\% 20$ podstaw $\% 20$ naukowych $\% 20$ metody\%20kinezjologii\%20edukacyjnej\%20oraz \%20konsekwencji\%20ich\%20stosowania.pdf> [15.08.2019].

[5] Najwyższa Izba Kontroli: <https://www.nik.gov.pl/aktualnosci/nik-o-przygo towaniu-do-zawodu-nauczyciela.html $>$ [11.04.2019].

[6] Polska Komisja Akredytacyjna: <http://www.pka.edu.pl/> [05.05.2019].

[7] researchautism.net: <http://www.researchautism.net/autism-interventions/intro duction-autism-interventions $>$ [14.08.2019].

[8] WHO: <https://www.who.int/classifications/icd/en/> [15.05.2019]. 